\title{
未然事故調查試行結果と事故との比較
}

\author{
山崎 祐介*・村山 義夫***遠藤＼cjkstart真*
}

\section{A Comparison of Marine Incidents and Marine Accidents}

\author{
Yusuke YAMAZAKI, Yoshio MURAYAMA and Makoto ENDO
}

\begin{abstract}
The marine incident is the important source of the information on marine accident prevention measures. In this paper, comparing the marine incidents with the marine accidents, authors made investigation into similarities of the occurrence situation on both.

And, the relation between the incident and the watchkeepers' duty state regarded as an important factor of the human errors could be analyzed furthermore.

The findings are as follows.

The marine incidents have many points of similarities to the marine accidents. And also, it became clear that the incidents happened around two hours later after the watchkeeping duty began.

Considering these findings, authors suggest the optimum procedure to establish a method to investigate the marine incident. At first, the factors of the marine incident and the accident should be investigated, and they should be compared repeatedly. And, the investigation of the obvious relation between marine incident factors and marine accident factors should be done.
\end{abstract}

\section{1. まえがき}

周知のとおり、STCW条約にもとづく船員の資質の向上、ポートステートコントロール、ISMコード等 の整備が進行中である。これらの基本的な事項を遂行することが、船舶の安全航行を確保するための前提 となる。しかし、これらの整備が進んでも、事故は予期し得ない事態によって起こり得る。それ故、前述 の基本的事項を推進させる傍らで、事故をもたらした原因の調査をすることが、事故再発防止対策にとっ て直接的であり、安全戦略を実行するための大きな推進力となる。

人為的海難原因についての調查・分析のあり方について、例えばつぎの指摘がなされている。「これまで の海難原因の追求にあたっては、主として海難当事者、関係者の処分等のために直接的な原因追求がなさ れてきたが、処分等とは別に再び同様な原因により事故が発生することを防止するという純粋な観点から の調査、分析があまりなされてこなかった傾向があると思われる。」(1)とされ、更に、現状では必ずしも十分 ではないと思われる事項として生理的・精神的要因の調查分析、管理的要因の調查が指摘されている(1)。

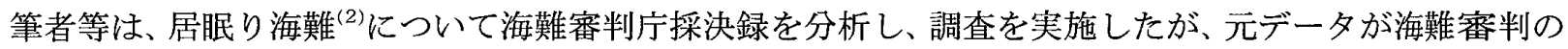
結果であることから多くの事項が欠落していた。それらは、乗組員の個人特性と心身状態の変化等の人的 条件、ならびに、航路、漁労船等、事故関係船舶以外の通航船舶等の環境条件で、直接原因を形成した背 景要因を追跡するために必要な要因であった。

一般に事故は、いくつかの不具合な事象が連鎖・集中して発生することから、安全管理では、作業上の

* 正会員 富山商船高等専門学校（率933-0293 富山県新湊市海老江練合1-2）

**正会員 財団法人 海上労働科学研究所（テ102-0083 東京都千代田区錮町4-5 海事センタービル） 
ソフト、ハード、環境、作業者個人、作業者集団についての総合的な対策が求められる。その対策は、過 去に起きた事故調査から、原因を知り、それを消去するための方策である場合が多い。その際、事故に関 与した当事者等からの事故原因に関する情報は、事故の責任等汃ら、その収集が必ずしも円滑になされな いことがある。海難においても同様であり、海難における人的要因の調查は、事故関係者が死亡したり、 または生存していても、事故関係者に係わる行政・刑事・賠償責任等が影響して、容易ではないことが推 測される。従って、その背景要因まで調查がなされることは希である。

未然事故は、災害を伴う海難に至る一歩手前の状況であり、それが、海難となるかどうかは偶然で決ま るといら、損失偶然の法則 ${ }^{(3)}$ があり、重大な損傷のある海難に至る陰には、軽微な損傷で済んだケースが多 く存在し、その陰にはさらに多くの損害のないケースがあることが分かっている。未然事故では、事故に なっていないことから、過去に起きた海難に比較して、事故関係者の人的要因を調查しやすい。筆者らは、 ごく軽微な損傷、無損傷のケースを未然事故として着目し、事故の原因とその背景を調査する方法を確立 するために、調査対象者と調査者の心理的関与を少なくする調查票調査を行った。海難審判にお打る裁決 率：損傷報告率：未然事故報告率の比を求めた結果、1：14：476であり、ハインリッヒの法則とほぼ同様 のピラミッド構造をなしていること、及び、発生率の確率的評価から海難と未然事故との関連を示唆(以下、 前報) した ${ }^{(4)}$ 。

最近、IMOにおいて、海難及びインシデントの調査のためのコード(5)が作成されたことは注目に值する。 このことは、未然事故の中から、事故の可能性とその要因を探る調查法が有効であるという、筆者らの見 解 ${ }^{(4)}$ と一致している。

しかし、報告される未然事故における因子は、報告者の主観を含むことから、実際にどのくらい現実の 事故に寄与するかを表す重要度指数が報告されている(6)。

そこで、本報告では、前報における未然事故調査と同様のデータを海難審判庁裁決録(以下、裁決録とい ら $)^{(7)}$ から作成し、両者の発生状況の類似性を検討した。さらに、前報の調查データにより、注目されなが ら海難審判では明らかにされていない要因として、ヒューマンエラーの重要なファクターと考えられてい る(9)、船橋当直者の勤務状態を取り上げ、未然事故経験との関係について分析してみた。

そして、これらの分析をふまえ、未然事故調查法の確立について考察した。

\section{2. 調査方法}

調查資料は、前報の未然事故調査の元データと、最近 1 年間の裁決録データである。両者の関係を調べ るために、共に抽出可能な事故状況に関する情報を同様の内容にカテゴリー化した。その項目は、事故当 事者、発生時刻帯、他船との見合い態勢、視界の状況、及び海域の広さである。

分析データは、100総トン以上の商船が漁船以外の他船に衝突しようとした未然事故のうち、明確に未然 事故経験時刻が記入されていた未然事故経験報告 (以下、未然事故という) と、裁決録における同種の海難 (以下、裁決海難という)であり、それぞれ、82件と83件である。

これらのデータ(以下、両データという)の各項目間の比率を比較して独立性の検定を行い、両データの 乘離を調べた。さらに、未然事故について、勤務時間、勤務時間帯と未然事故経験の時機等について検討 した。

\section{3. 調査結果}

\section{1 両データの比較}

分析対象の属性内訳は、表 1 に示すとおりである。未然事故は、裁決海難に比べ、大型船、旅客船が多 くなっている。

旅客船が、比較的大型で、旅客船一隻あたりの航海士が比較的多いことから、未然事故当事者の職種に 航海土の件数が多い結果となっている。表 1 参照。

(1) 発生時間帯

海難及び未然事故の発生時閒帯の割合は、図 1 に示すとおう、裁決海難では00〜04時、04〜08時、12〜 
表 1 諸データの属性

\begin{tabular}{|c|c|c|c|c|}
\hline & & & 末然事故 & 裁決海難 \\
\hline \multirow{3}{*}{ 総 } & $1-199$ & 度数 & 19 & 17 \\
\hline & $\mathrm{t} \circ \mathrm{n}$ & 列\% & 23.2 & 20.4 \\
\hline & $200-499$ & 度数 & 26 & 42 \\
\hline \multirow[t]{2}{*}{ 卜 } & $\mathrm{t} \circ \mathrm{n}$ & 列 \% & 31.7 & 50.6 \\
\hline & $500-699$ & 度数 & 11 & 12 \\
\hline \multirow[t]{2}{*}{ ン } & $t \circ n$ & 列\% & 13.4 & 14.5 \\
\hline & 700 ton & 度数 & 26 & 12 \\
\hline \multirow[t]{3}{*}{ 数 } & 以上 & 列\% & 31.7 & 14.5 \\
\hline & 合計 & 度数 & 82 & 83 \\
\hline & & 列\% & 100.0 & 100.0 \\
\hline \multirow{10}{*}{ 船 } & 貨物船 & 度数 & 37 & 56 \\
\hline & & 列\% & 45.2 & 67.5 \\
\hline & タンカー & 度数 & 26 & 22 \\
\hline & & 列\% & $31 \cdot 7$ & 26.5 \\
\hline & 旅客船 & 度数 & 12 & 3 \\
\hline & & 列\% & 14.6 & 3. 6 \\
\hline & 作業船 & 度数 & 7 & 2 \\
\hline & & 列\% & 8. 5 & 2. 4 \\
\hline & 合幛 & 度数 & 82 & 83 \\
\hline & & 列\% & 100.0 & 100.0 \\
\hline \multirow{3}{*}{ 䏊 } & 船長 & 度数 & 28 & 44 \\
\hline & & 列\% & 34.2 & 53.0 \\
\hline & 航海士 & 度数 & 44 & 24 \\
\hline \multirow[t]{5}{*}{ 種 } & & 列\% & 53.6 & 28.9 \\
\hline & 甲板長等 & 度数 & 10 & 15 \\
\hline & & 列\% & 12.2 & 18.1 \\
\hline & 合部 & 度数 & 82 & 83 \\
\hline & & 列 \% & 100.0 & 100.0 \\
\hline
\end{tabular}

16時、16時〜20時に多く、未然事故は、00～04 時、04〜08時、16〜20時、20〜24時に多い。

比率の検定によると両データは独立であると はいえず、両データとも、16時から00時、00時〜 08時の時間帯に約 8 割を占めていることが、裁 決海難と未然事故の共通した傾向となってい る。図 1 参照。

（2）他船との態勢

ここにいら態とは、勢と海上衝突子防法におけ る見合い態勢を含む単純な幾何学的相対見合い 態勢を意味する。

それぞれの割合は、図 2 に示すとおり、兩デ 一タとも、「横切り」態勢が約 3 分の 2 を占めて 多いことで共通している。また、未然事故は裁 決海難に比べて「行き会いかが若干多く、「追い 越し」、追い越され」態勢が若干少ない。両デー タの比率の差の検討による独立性は認められな 认。四 2 参照。

\section{(3) 環境}

(1)海域の広狭

ここにいう「狭い海域」とは、一般の船員が持 つ、大雑把な概念に従ったもので、海上衝突予 防法における狭い水道等を含む、広い海域では ない海域を意味する。裁決海難では、約 5 海里

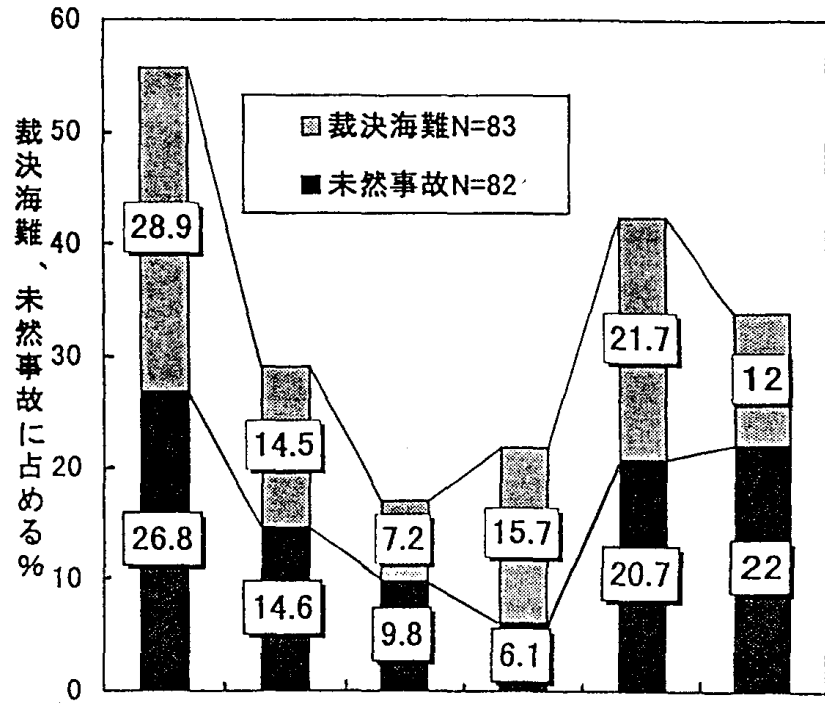

$00-04 \mathrm{H} \quad 04-08 \mathrm{H} \quad 08-12 \mathrm{H} \quad 12-16 \mathrm{H} \quad 16-20 \mathrm{H} \quad 20-24 \mathrm{H}$

図 1 事故の時間带

（N=165，Pearsonのカイ2乗有意確率0.284）

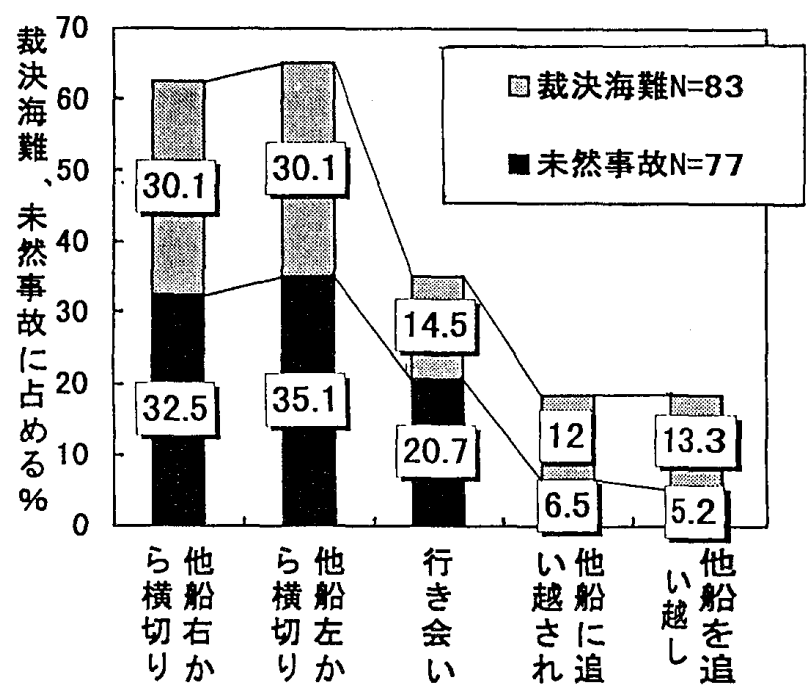

図 2 他船との態勢

（ $\mathrm{N}=160$, Pearsonのカイ 2 乗有意確率0.252）

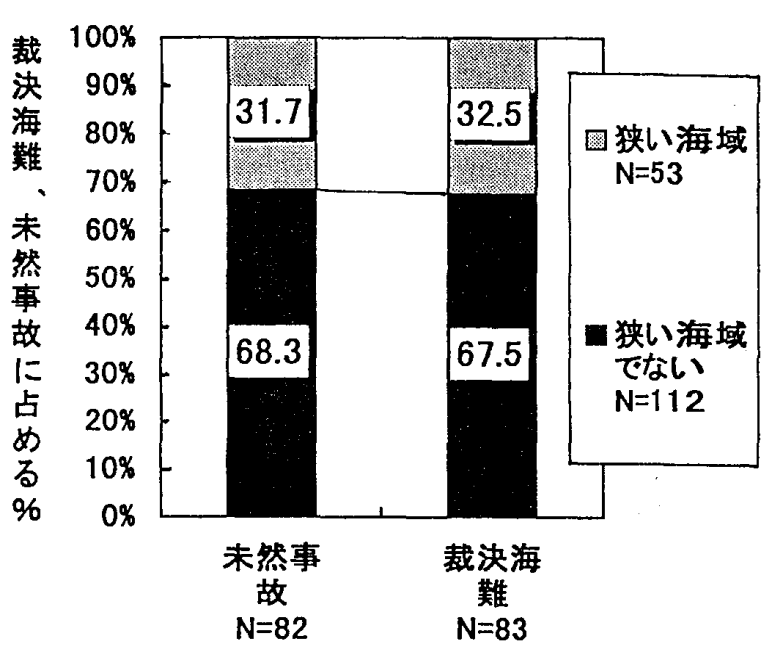

网 3 海域広狭の影響

（ $\mathrm{N}=165$ ，Pearsonのカイ 2 乗漸近有意確率 0.910 ） 
以下の航行幅 (港内と、瀬戸内海の一部海域 を含む。)であった海域を狭い海域とした。

それぞれの割合は、図 3 に示すとおり、 狭い海域が両データとも全体の約 3 分の 1 をしめておう、両データは独立ではない。

図 3 参照。

(2) 視界の状態

ここでいら、「視界不良」とは、海上衝突 予防法における視界制限状態を含む、航海 士が視界の程度に注意を要した程度の大雑 把な状況である。裁決海難では、裁決録に 「視界が良好」と記載されたもの以外、また は、 2 海里以上の視程が記載されたもの以 外を視界不良とした。

図 4 亿示すとおり、両データとも、全体 の約 3 分の 1 が「視界不良」で占められ、両 データは独立ではない。図 4 参照。

\section{(4) 当直者の職種}

図 5 に示すとおり、両データは独立で、 似通った分布とはいえない。船長で未然事 故経験が少なく、一等航海士から三等航海 士で未然事故経験が多くなっており、前述 したとおり、両データの属性の差異からの 結果であり、さらに、未然事故の報告態度 が影響している可能性がある。図 5 参 照。

\section{2 勤務時間と未然事故の関係}

（1）未然事故経験前の総勤務時間

未然事故を経験した時刻からさかのぼっ た12時間前の、総勤務時間の度数分布を求 めると、図 6 に示すとおりとなる。4 時間 を平均値として、バラツキが大きい。 4 時 間当直 8 時間休息の一般的当直の他に、入 出港やシフトがあるときや、所定の当直パ ターンが定まっていない場合等、勤務の内 容は多様である。図 6 参照。

なお、未然事故を経験した時刻からさか のぼった24時間前の、総勤務時間は、平均 値7.2時間、標準偏差3.38である。

また、それぞれの勤務時間が液間 (19時以 後07時まで) か、昼間 (07時以後18時台まで) を調べたところ、図 7 に示すとおり、総勤 務時間が短いものでも夜間の割合が約 6 、 7 割と多くなっている。図 7 参照。

(2) 入直後未然事故経験までの経過時間 (以下、入直後経過時間)

調查票にお打る、航海当直制、未然事故

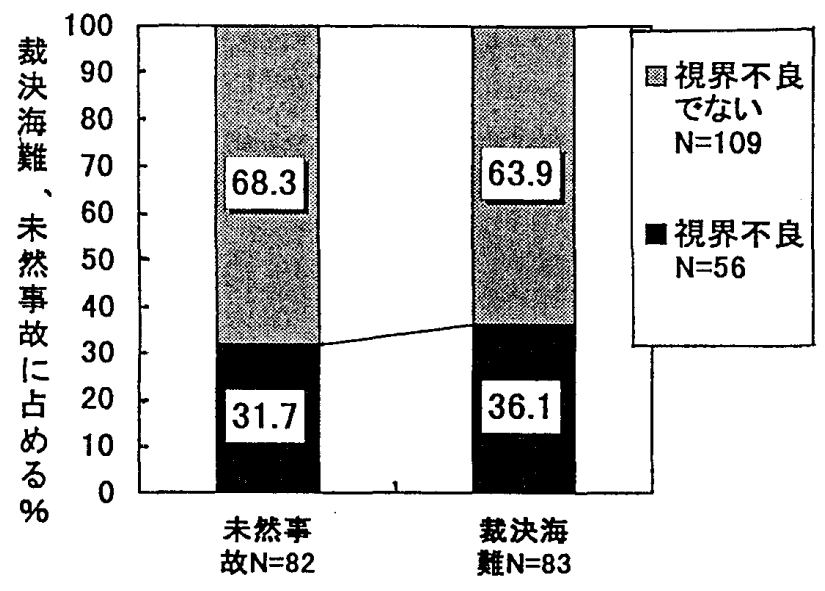

図 4 視界の影響

（ $\mathrm{N}=165$, Pearsonのカイ 2 乗漸近有意確率 0.457 )

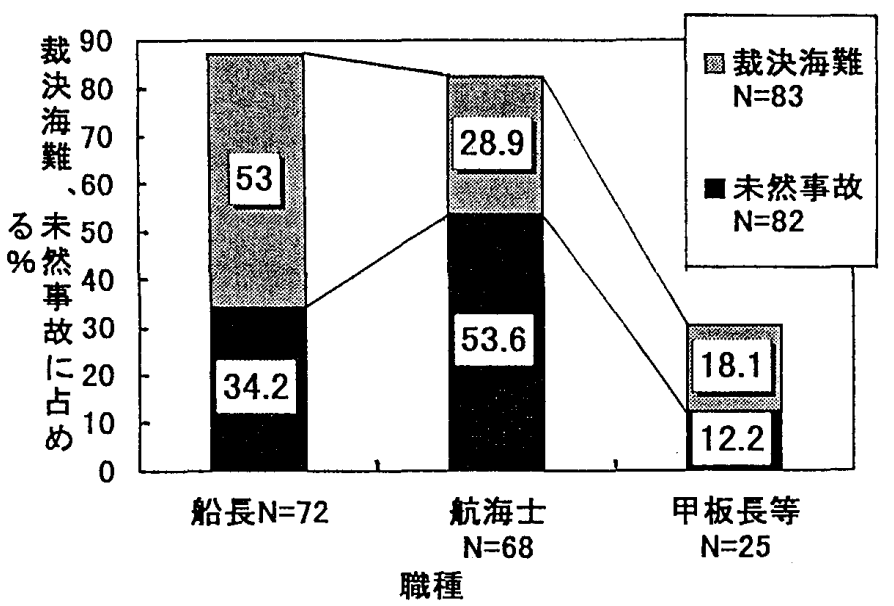

図 5 事故当事者の職種

（ $\mathrm{N}=165 ，$ Pearsonのカイ 2 乗漸近有意確率 0.000$)$

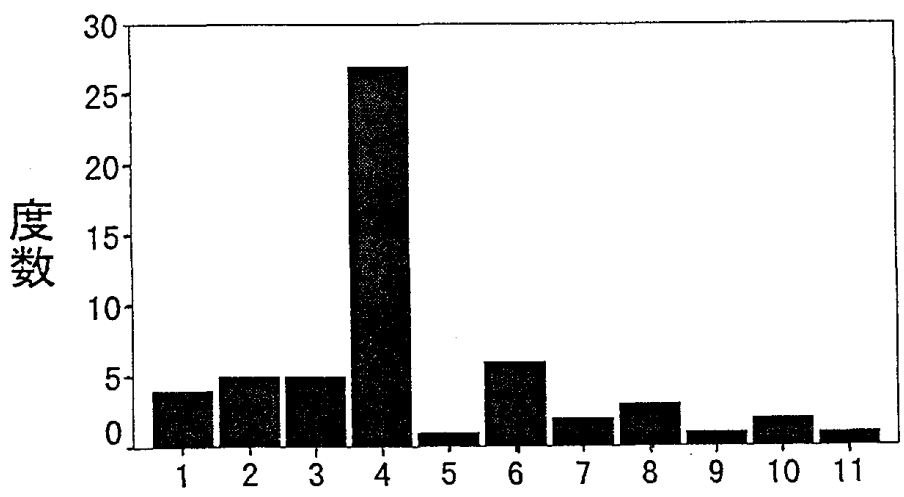

12時間前の総勤務時間(時間)

図 6 未然事故12時間前の総勤務時間 $(\mathrm{N}=57$ 中央值4.0 平均值4.49 標準偏差2.25） 
を経験した当日と前日の勤務時間帯、 及び未然事故経験時刻データから、未 然事故を経験した航海当直に入直して から末然事故経験時刻までの経過時間 を入直後経過時間として調べた。航海 当值制が「固定」または「順送り」かつ、 未然事故経験勤務時間带とその前後の 勤務時間带の勤務時間数が同じ場合、 その定型的な勤務時間带を航海当直時 間帯とみなした。また、一連続当直が 4 時間に満たないものを集計から除外 した。これらの条件を満たす34サンプ ルについて集計し、入直後経過時間の 時間别分布を求めた。

入直後経過時間は、図 8 に示すとお り、入直後 2 時間を中心に分布して拉 り、3 時間以上のものが約 3 割を占め ている。図 8 参照。

\section{4. 考察}

未然事故試行調查と現実の海難は、 その発生時間帯、他船との態勢、視界 の状態及び海域の広狭において、ほぼ 似ていた。また、海難審判では知るこ とが出来ない勤務との関係について調 ベることが出来た。さらに、現実の海 難は、同じ船で海難が一旦起きてしま えば、その当直中には再び海難は起こ らないので、その条件確率事象として の性格から当直初期に起こることが多 $<^{(9)(10)(11)}$ 、以後の時間带で漸減してい る。しかし、未然事故は、当值時間带 に一様に起こっており、当值後半に起 こる事故の要因を調べるうえで有効で あることが分かった。

また、未然事故因子の一例として、 未然事故経験前の総勤務時間を取り上 げ、未然事故の船橋当值入直後経過時 間との関係を調べたが直線的な相関関 係はなかった。

未然事故の原因を入直後経過時間や 12時間前の総勤務時間といら要因で統 計的に説明することは難しく、それら は、多くの事故要因の一つの変数であ るといら可能性がある。この場合、影 響する他の要因を明らかにして、その

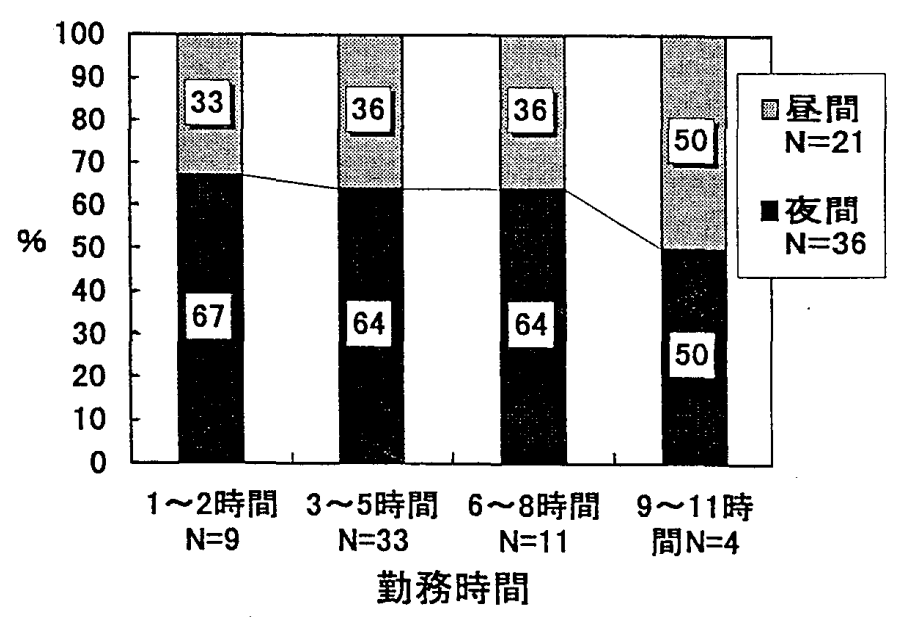

図 7 昼夜と未然事故経験12時間前の勤務時間 （ $\mathrm{N}=57$ ，Pearsonの力イ2乗漸近有意確率0.950）

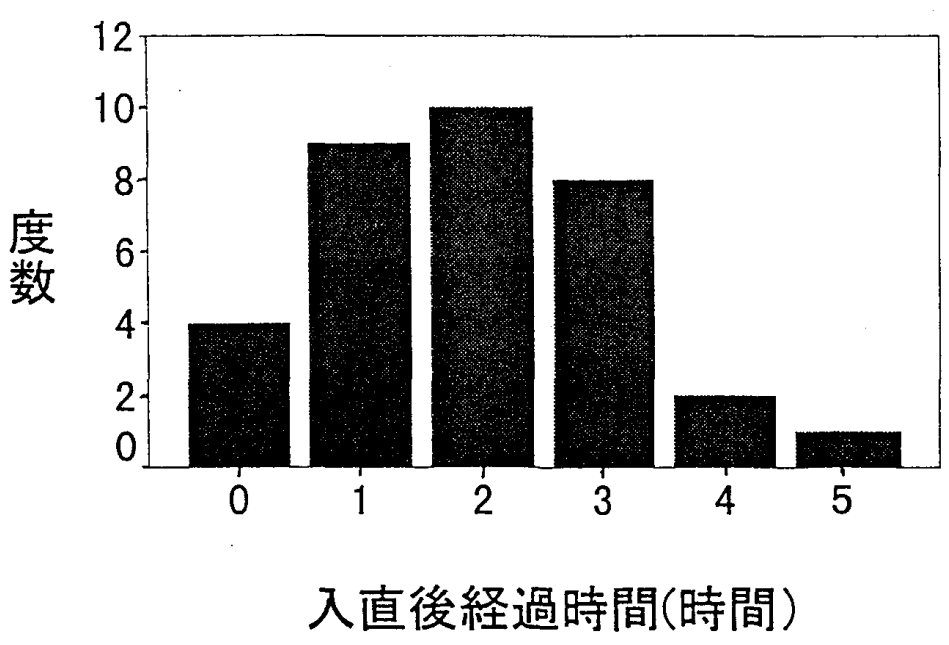

図 8 未然事故の入直後経過時間 $(\mathrm{N}=34$ 平均值1.94 中央值2.0 標準偏差1.23)

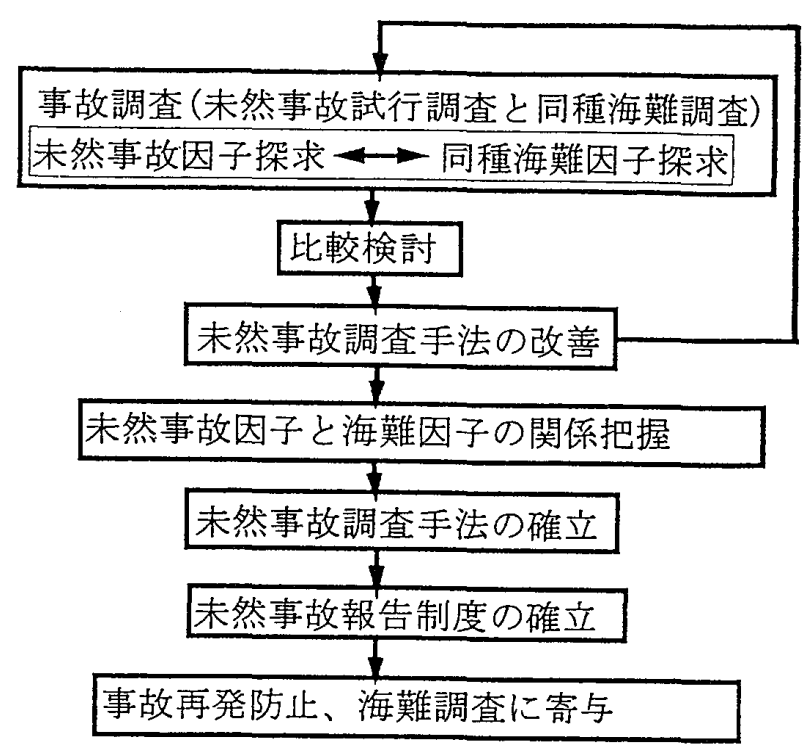

図 9 未然事故調査手法の開発 
影響を除いて一要因の評価をするか、多因子を同時に評価するようなデータを取得できるように改善する 必要がある。

しかし、事故要因の多様さとその影響程度の確定の困難さから解析的に可能とは考えにくい。事故の多 面的な背景要因との関係を探るための未然事故調查法を確立することが必要であるが、そのためには、図 9 に示すとおり、未然事故試行調查と同種の海難の調查を行い、両者の事故に影響を与えた因子を抽出し て比較検討し、海難発生のメカニズムと影響した背景を知り得る未然事故試行調査法とする改善作業を繰 り返す必要がある。

そして、未然事故因子と海難因子の関係を把握し、未然事故調查法を確立すれば、未然事故報告制度に 発展させ、有効な事故予防策を施すことが可能となる。また、未然事故調查の成果を得て、海難審判に掠 ける海難調查も改善することが必要で、それを海難防止対策に結びつけることが重要である。図 9 参 照。

\section{6. あとがき}

一般に、事故再発防止のための事故調查は背景要因の調查が主であり、IMOにおいても、その方向で進 んでいる。しかし、事故当事者は責任等から真相を出し渋り、背景要因の調査は難しいことが考えられる。 そこで、筆者らは前報において、未然事故調查の有用性を提起し、今回は、現実の海難との対比について 調查し、そ扎りの成果が得られたので報告した。しかし、例えば、総勤務時間と航海当直入直後未然事 故までの経過時間との関係については、前述したように、一つの要因の傾向で単純に海難の原因をみるこ とはできない。また、要因をつぶさに洗い出すことや、その重みの確定の困難さから、解析的に因果関係 を求めることも困難であろう。そこで、海難と未然事故試行調査を繰り返し試行して、それらの因子を比 較検討しながら改善することが近道であると考えられる。今回の報告は、その第一歩であった。

海難は人間の病気に似ている。有効な治療のためには、まず、適正な診断が必要である。そして、表面 的な症状の対症療法ではなく、根本的な、治療と予防が必要である。

海難は今や環境保全とリンクしており、海難調查が各国独自の体制、方法でなされており、必ずしも円 滑な原因究明ができないこと等から国際化の時代を迎えた。

筆者等の調查結果、及び考察に対する忌憚のないご意見と、我が国においてもインシデント調査の議論 が今、盛んになることを期待するものである。

\section{参 考 文 献}

(1) 藤岡賢治：海難政策論p71～p72，成山堂，1994.

（2）村山義夫・山崎祐介・遠藤 真・高橋 勝・ 日當博喜：居眠り海難の分析 I 一居眠り要因分析一, 日 本航海学会論文集第87号 p73〜 78，1993.

（3）安全工学協会編：安全工学便覧，p10，コロナ社，1976.

（4）村山義夫 - 山崎祐介 - 遠藤 真：未然事故調查試行結果について，日本航海学会論文集第 98 号, $p$ 257 264, 1998.

(5) IMO : CODE FOR THE INVESTIGATION OF MARITIME CASUALTIES AND INCIDENTS RESILUTION A. 849 (20) Adopted on 27 November 1997.

(6) 林 喜男：人間信頼性工学， p40，海文堂出版， 1985 .

（7）海難審判協会：海難審判庁裁決録 (平成 8 年 $1 \cdot 2 \cdot 3$ 月分海難審判庁裁決録～平成 9 年 $1 \cdot 2 \cdot 3$ 月分海難審判庁裁決録).

(8) T. K. Dehmel : Incident reporting - problems, benifits and possible European approach Proc. Int. Sym. Human Factors on Board, ISHFOB '95, Germany, 1995, (13-20).

（9）海難憲判庁：内航貨物船の海難の実態，1995.

(10) 海難審判庁：内航タンカーの海難の実態，1996.

(11) 海難審判庁：旅客船海難の実態，1997. 


\section{質 疑 応 答}

斉藤和夫(鳥羽商船高等専門学校)：未然事故、事故の定義についてはどのようにお考えでしょうか。

山崎祐介：重い損失を伴う事故(災害)を事故とし、その重い事故の背後に多く存在する、ごく軽微な損失 または無損失な事故を未然事故として考えています。前報における調查票において、回答者にヒヤリと した程度を、「なんとか避けられた」、「ほの接触」「損傷があった」という 3 段階で聞いています。本 論では「なんとか、避けられた」及び「ほんの接触」のヒヤリの程度を未然事故としています。また、海 難を起こして海難審判の対称になった場合を事故としています。

古荘雅生 (神戸商船大学)：災害発生率の表現としてよく引用されるハインリッヒの法則との関連について どのようにお考えでしょうか。

山崎祐介：前報において、海難審判裁決率：損傷報告率：無損傷報告率=1：14：476であるとし、ハイン リッヒの法則の比に近かったことを報告し、未然事故調查方法によって、海難原因調查が可能であるこ とを示唆しました。重い損失を伴う事故の背後に、多くの軽微な損失を伴う事故があり、その背後には 更に多くの無損失事故が存在するという、いわばピラミッド構造が形成されておれば、ハインリッヒの 言うそれらの出現率の值はともかくとして、そのピラミッド構造の中で、重い事故は、偶然性に支配さ れて起こるという、損失 (災害) 偶然則を採用し、未然事故情報が有用であることを証すものと考えてい ます。 